\title{
A Reflective Study on Intercultural Transmission and Appreciation among Silk Road Countries
}

\author{
Chengcheng Liu \\ School of Liberal Arts, Renmin University of China, Beijing, 100872, China
}

\begin{abstract}
The paper firstly introduces the Belt and Road Initiative proposed by China with a global vision and long-term benefits advocating comprehensive cooperation among the Silk Road countries in infrastructure, politics, economy, finance and culture. Then it focuses on the theoretical analysis of culture, intercultural communication and cultural effects of the ancient Silk Road which had been transformed from a trading route to a comprehensive one containing economic ties, political trust, cultural exchange and common prosperity. The economic energy and cultural vitality of this ancient road is revived under the Belt and Road Initiative framework in accordance with the principles listed in the third part of the paper including respecting different cultural concepts, contributing our new thoughts, understanding other cultures with cultural empathy and making mutual choices in cultural interaction. Our great mission today is to contribute to the common development in and beyond cultures and ultimately attain the goal of building a community of shared future for all humankind.
\end{abstract}

Index Terms - The Belt and Road Initiative, the Silk Road, culture, intercultural communication, intercultural appreciation

\section{INTRODUCTION}

The Belt and Road Initiative is a global initiative proposed by China, which creates a brand-new international relationship model aimed at enhancing and promoting economic cooperation and common development among Silk Road countries so as to implement the vision of building a community of shared future and shared virtues. Our objectives are comprehensive, multi-leveled, and wide-ranged interactions and development in politics, economy, civilization, and culture; they are not solely limited to the construction of economic strategy and promotion of economic cooperation and advancement, for the single economic strategy cannot achieve the ultimate goal of soul-to-soul bonds. Our top priority is to realize this goal from humanistic orientation, but not from the functional one because the cultural resources are getting more with more digging while the energy resources are just the opposite. As to those vast-invested, highly-risky projects like highways, bridges, ports, tunnels, industrial parks and infrastructures, it is necessary to supplement such asset-light projects like culture, education, health, tourism or professional service to assist in and facilitate those long-cycled and risky projects. It is necessary to strengthen the overall plan and coordination, and to improve the theoretical study and construction of the discourse system. It is also necessary to promote the publicity and guidance to reinforce the fostering of international transmission ability. All of these efforts constitute solid theoretical foundation, publicity support, and cultural condition. The cultural condition is the key point stressing what the Belt and Road Initiative pursues: it is not only commercial opportunity to break business barriers, but also cultural opportunity to break cultural barriers that work together to build the community of a shared future and values on the basis of multiculture.

Priorities should be given to cultural development so as to further deepen cultural exchange and cooperation among Silk Road countries. The ancient Silk Road and Maritime Silk Route derived from the aspirations of cultural communication and integration of diverse ethnicities; these economic and cultural roads have been transformed into the prime platform on which culture and arts are exchanged and commercial activities are carried out heatedly. The Belt and Road Initiative covers dozens of Silk Road countries and benefits billions of people who create various civilizations in different styles and play great parts in the treasure house of human civilization. We should make the most of these plentiful cultural heritages to inherit and develop the Silk Road culture which represents the appealing cultural symbol: to promote the common development of different civilizations through intercultural communication and multicultural integration.

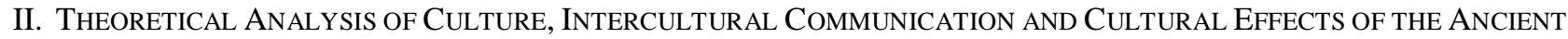
SILK ROAD

\section{A. The Analysis of Culture in Definition and Components}

Culture has very broad scope of connotation and extension. Although it's hard to come to a commonly-accepted definition of culture, we can understand its elements and features through the following analysis: Bates and Plog (Bates \& Plog, 1990) propose a descriptive definition of culture: Culture is a system of shared beliefs, values, customs, 
behaviors, and artifacts that the members of a society use to cope with their world and with one another, being transmitted from generation to generation through learning. According to this definition, culture includes everything from diet and dialect to dress and dwelling (so called four Ds). Culture, as a comprehensive demonstration of the people living in the same territory, can be learnt in many ways and from a variety of sources, such as their routine lives, religious ceremonies, folk tales, legends, arts, proverbs, mass media, and, above all, their formal education. The best way to figure out a foreign country and their countrymen is to approach their lives, for their lives is their panoramic display of their cultures.

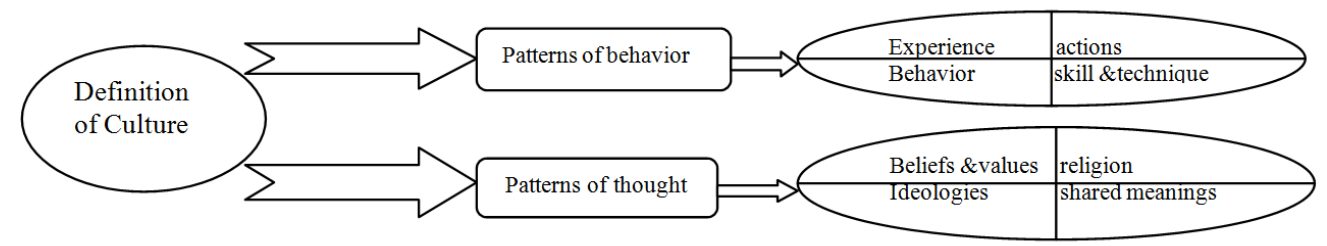

Fig.1: The descriptive definition of Culture according to Bates and Plog.

\section{B. The Analysis of Intercultural Communication in Definition, Significance and Effective Approaches}

Intercultural communication is the communication between people whose cultural perceptions and symbol systems are distinct enough to alter the communication event. (Samovar \& Porter, Stefani, 2000) Here, intercultural communication includes interracial communication, interethnic communication, and intercultural communication. At present, with the rapid development of modern technology in computer, transportation and communication, more and more countries are being involved in global interactions in politics, economy and culture. Once international communications get normal and highly-frequent, intercultural communication will inevitably turn into a hot issue.

Different ethnic groups interacted and integrated during the development process of the Chinese nation. The Silk Road dates back to the $2^{\text {nd }}$ century B.C. when ancient Chinese people communicated with people from central Asia, west Asia, Africa and Europe. The introduction of Indian Buddhism, the eminent monk Jian Zhen's visit to Japan, and Zheng He's sailing to West Ocean, all these activities included complex processes of intercultural communication. (Hu, 1999) Intercultural communication has been a long-term atmosphere since antiquity, and the reason why it attracts people's increasing attention nowadays is that the communication among people in different countries, nations and races is more frequent and convenient thanks to the fast development of transportation and computer technology. The anywhere-anytime Internet access enables intercultural communication to take place at any moment. With the largescaled shifting population and frequent communication, intercultural communication is the most prominent feature of this era and also the most important and valuable activity in our routine lives. Harms (Harms, 1973) believes that the communication in these two decades is featured by intercultural element, which is the fifth stage of human's communication. Indeed, the importance of intercultural communication can be compared to the language production.

In the process of intercultural communication, there are various obstacles to keep us from conducting successful and effective communication including cognitive misunderstanding, stereotyping and ethnocentrism. (Hu, 1999) To overcome this negative psychological cognition, the intercultural scholars designed many approaches in different levels to help decrease the bad effects of the invalid communication. According to Brislin's summary (Brislin, 1986), there are generally six approaches contributing to effective communication covering information-provided training (a traditional approach to introduce the history and culture by means of speech, video, discussion, etc.), reason-analyzed training (a practical approach to narrate an event reflecting cultural conflict and offer different explanations, and then select the right one), cultural awareness-enhanced training (an operational approach to devise very dramatic activities to help the trainees learn about their own cultures), cognitive behavior-reformed training (a seldom-used approach to improve the cognition so as to change their behavioral pattern), experimental training (a role-play and field-training approach to devise some foreign cultural circumstances to make the trainees solve various problems relevant to the culture), and interaction training (an interactive approach to carry on the actual intercultural communication among the trainees and the expert or representative from other culture). After a period of formal and intentional intercultural training, the trainees will, at the first level, have a rough understanding about the foreign cultures through travelling or textbook, experiencing its strangeness and exotic atmosphere; at the second level, they find some important and subtle differences of foreign cultures from theirs due to cultural conflicts, experiencing depression with unusual conduct; at the third level, they are acquainted with the important and subtle features of foreign culture by means of rational analysis, accepting it in cognition; at the fourth level, they learn to see everything from the perspective of the local people because of longterm living experience in foreign cultures, accepting it in emotion. (Hanvey, 1979) Table 1 illustrates the distinct and concrete description of diverse training approaches and training goals. 
TABLE1:

\begin{tabular}{|c|c|}
\hline \multirow{6}{*}{$\begin{array}{l}\text { Six training } \\
\text { approaches to } \\
\text { intercultural } \\
\text { communication }\end{array}$} & 1. Providing information training approach \\
\hline & 2. Analyzing reason training approach \\
\hline & 3. Cultural awareness-enhanced training approach \\
\hline & 4. Cognitive behavior-reformed training approach \\
\hline & 5. Experimental training approach \\
\hline & 6. Interactive training approach \\
\hline \multirow{4}{*}{$\begin{array}{l}\text { Training goals } \\
\text { for intercultural } \\
\text { awareness in } \\
\text { four different } \\
\text { level }\end{array}$} & 1. To have rough understanding about the foreign cultures \\
\hline & $\begin{array}{l}\text { 2. To see some important and subtle differences of the foreign } \\
\text { cultures from ours }\end{array}$ \\
\hline & $\begin{array}{l}\text { 3. To be acquainted with the important and subtle features of foreign } \\
\text { cultures }\end{array}$ \\
\hline & 4. To learn to see everything from the perspective of the local people \\
\hline
\end{tabular}

\section{The Historical Comments on the Ancient Silk Road and Its Significance in Cultural Exchange and Integration}

The Silk Road is a concept initiated by geologist Ferdinand Freiherr von Richthofen, a distinguished scholar from Germany who invented "die Seidenstrasse" (the Silk Road) in the first volume of his Chinese research book published in 1877. Maybe he used this term very casually, but this definition helped him establish his prominence in the study of the Silk Road. In view of this historical fact, the western research in Silk Road can date back to 1800s. Chinese expert Lv Wenli believed that the Silk Road originated from the mutual attractions of different cultures and the communication of civilization, interaction and integration on the ancient Silk Road became the promoter in the history of human civilization progress, leading the directions of the world historical process. He classified the civilizations into four aspects including material, technology, arts and ideology, giving the following names for the Silk Road: the Exchange Road of Material Resources, the Dissemination \& Promotion Road of Advanced Technology, the Blending Road of Eastern \& Western Arts, and the Symbiotic Road of Religions and Collisions of Different Ethnic Ideas. (Zhao, 2017) East-West silk trade had a long history of about four-thousand years, much earlier than Zhang Qian's travel to western countries from the capital of Tang Dynasty, Chang'an, to the European continent. (WEI, 2017) Silk is not only a product of trading contact, but also the link for cultural exchange. With the prosperity of the Silk Road, artistic forms from western countries were firstly introduced to Sinkiang and Hexi District of Gansu Province, and the first cultural convergence of home and abroad can be traced back to Han and Tang Dynasties. What they mainly absorbed was the cultures from the Western Regions (Central Asia and Western Asia) and South Asian Sub-continent (Baidu, 2017) where Buddhism were popular. Buddhism was remolded, while its essence was digested, being integrated into Confucianism tactfully in the process of Buddhism's developing in China. Owing to the wide diffusion of Buddhism, many cultural aspects in China were influenced profoundly. As a result, the Silk Road is not only a commercial trading road and cultural corridor, but also a civilized road opening up to the outside world, whose history is full of friendly communications between ancient China and the world.

The reason why Silk Road became the main artery of economic exchange and cultural interaction was that this particular road was firstly a passage of economy and trade. Apart from the study on its material spreading, we should focus on its function of cultural exchange and integration behind Silk Road and its remarkable significance in the modern world. After experiencing the social unrest and changes around the world, the memory of ancient Silk Road almost faded away, but the Silk Road cultures which have been inherently embedded in the long journey, the historical heritage, the literary production, the works of art and the folk life shouldn't be forgotten forever. The Silk Road cultures are integrated cultures revolving around northwest culture, west culture, immigrant culture and multi-ethnic culture, reflecting multiple characters of openness, generosity, straightforwardness, familiarity and fun. All those excellent cultures that Chinese history absorbed from other cultures through the Silk Road played very decisive roles in sustaining and inheriting our Chinese local cultures, contributing a lot to the development of the continuous Chinese cultures and civilizations for thousands of years. The lesson we can learn from the history of the Silk Road is that only by opening up and learning from successful experiences of the world can we promote human being's civilization; the mutual learning from other cultures among different ethnicities around the world is the essential feature of human civilization, and also a crucial impetus to foster civilization. Our challenge today is how to deal with relationships among different cultures and how to promote mutual understanding of other cultures to attain common improvement. (News Agency, 2016)

\section{BASIC PRINCIPLES OF INTERCULTURAL TRANSMISSION AND APPRECIATION AMONG SiLK RoAD COUNTRIES}

From the historical perspective, the human society was in the era of mega development, transformation and adjustment. As the strength of western countries represented by America descended in recent years, they began to worry about the increasing power from the newly-revived and developed countries, forming very severe strategic anxiety and maladjustment. In addition, the global economy has been gloomy since the financial crisis in 2008. At this critical moment, the Belt and Road Initiative was proposed and made known to the world. Under the framework of this initiative, to strengthen the cultural exchange with foreign countries is the effective approach to obtain solid support from the masses. Meanwhile, it is conducive to eliminate misunderstanding, furnish conditions for solving geopolitical 
contradictions, sovereignty disputes, and trade frictions as well. Furthermore, it can be beneficial for the establishment of a more just and equal international order. Given the slow development of some Silk Road countries, the complex international political environment, the distinctive cultural differences and religious conflicts among different ethnic groups, the Belt and Road Initiative is bound to go through a long-term improvement before attaining its ultimate perfection. In order to reduce religious conflicts, we should take full advantage of positive energy of the religion in the process of cultural exchange. The common principle is to seek commonness while reserving differences and to pursue the common-shared cultural connotation and value orientation. People-to-people bond is the social foundation and supreme goal of the Belt and Road Initiative, so we should carry forward the spirit of friendly cooperation and harmonious co-existence along the Silk Road by promoting extensively cultural and academic exchange, personal communication and cooperation, media cooperation, youth and women exchange and volunteer services so as to win public support for deepening bilateral and multilateral cooperation.

China has transformed into the era of Global Citizen; the Belt and Road Initiative is becoming the new focus and Chinese people are paying more and more attention to improving relationships with the Middle East, Central Asia, North Africa, Central and Eastern Europe, and Latin America. According to the recent statistics, there have been more than one thousand new books about the Belt and Road covering history, politics, law, economy, culture, linguistics and arts, over 10 million relevant news reports, 30 Chinese cultural centers in the countries along the Belt and Road by the end of 2016. There is an obvious growth in the number of Chinese educational aid and cultural cooperation in relevant Silk Road countries. China offers ten thousand governmental scholarships to the countries along the Belt and Road in order to implement Educational Action to Promote the Belt and Road. Till now, China and other Silk Road countries have held National Cultural Year for 20 times, signing 43 intergovernmental agreements in cultural exchange. Under the guidance of the Belt and Road Initiative, the vast areas of cooperation in transnational academic research, technological innovation, ecological protection, and the improvement of people's lives will be conducted extensively and deeply in accordance with the following principles:

\section{A. To Respect Different Concepts in Order to Make Cultural Communication Persistent and Prosperous}

The fundamental principle of intercultural communication is the dialogue reflecting face-to-face relationship instead of unified ideas or thoughts. When Chinese culture is transmitted to other countries, we shouldn't depend on the cultural influence or unilateral instilment to promote its transmission. Instead, we can take part in building a multicultural world encouraging diverse cultures to co-exist and learn from one another through approaching and understanding other cultures. Any culture in this world is equal to another one, so our attitudes toward any culture should be filled with respect and humility.

Chinese culture is characteristic of its ancient philosophical wisdom: harmony actually fosters new things and similarity doesn't sustain. This philosophy emphasizes that only mutual interaction and enrichment can urge different civilizations to rejuvenate and continue to grow. Under the guidance of ancient philosophy, the new generation of cultural inheritor should take an equal and moderate attitude to transmit our culture to other countries, learning and absorbing the merits and advantages of foreign cultures. Through positive and equal cultural communication, we can really promote common development and accomplish multicultural interaction and prosperity.

In the modern world, the starting point of cultural transmission is not spiritual colonization, but cultural sharing, cultural co-existence and cultural co-prosperity. In view of our common wish, the worldwide equal dialogs will be the central premise to make different cultures develop according to the combination of their own cultural genes and modern characteristics. As a matter of fact, many difficult and long-period global issues tend to derive from cultural differences and misunderstanding. Once we arrive at the consensus that cultures should be maintained and developed in accordance with their own genes, characteristics and their own pace instead of cultural assimilation, coercion or unification, most of those irreconcilable conflicts and hot issues around the world will be defused gradually, and resolved eventually.

\section{B. To Contribute Our Chinese New Thoughts to the World as the Core of Chinese Cultural Transmission}

$\mathrm{Li}$ Zehou, the most influential thinker in the late $20^{\text {th }}$ century in China, believed that the fundamental principle of Chinese aesthetics was to refine temperament, and to cultivate sentiment in order not to turn people into objects, or into people with extreme utilitarian pursuit. (Shi, 2016) As a result, the most important cultural heritage in China is the aesthetic culture resisting materialization and the big problem we confronted now is how to return to the original aesthetic culture. The ideological core of sentiment put forward by Li Zehou was resonated among western scholars, advocating sense and sentimentality to replace pure rationality. Another Chinese professor Zhao Tingyang advances the theory of Tianxia (the Universe) System which regarded Tianxia as the only greatest one and considered various cities could be in harmonious co-existence, understanding one another and eliminating absolute national concept. (Zhao, 2011) Chinese and western scholars agree that our cultures go ahead on the basis of mutual complement, as Lin Yutang, one of the well-known Chinese cultural communicators in foreign countries, once said that the ideal life was a mutual complement of Chinese and western cultures.

According to the brief introduction of two Chinese modern scholars and their creative ideas, we know that Chinese philosophy doesn't stop going ahead, but keeps up with the modern times, which represents the key element of Chinese cultural genes. With the new problems and circumstances arising across the world, the new thoughts on the material and 
spiritual world will be turned into proper and rational ones. Chinese and western cultures can be complementary, moving forward together at the same time.

\section{To Understand Other Cultures with Cultural Empathy}

In the process of Chinese and western cultural communication, the premise is to have a thorough understanding about our own Chinese culture with passion and devotion. Without Chinese cultural details, what and how can we convey to our communicative companions? With deep insight of Chinese cultural information, we can transmit a great number of cultural resources and share with our counterparts. Lin Yutang wrote My Country and My People (in 1935) and The Importance of Living (in 1938) full of passion for his motherland, China, and his countrymen. Only with deep love for our own country and our own culture can we Chinese become better cultural inheritors and transmitters. Secondly, we have to know about the westerners' cultural tastes through which we can provide with proper cultural products. It isn't the cultural instillation or propaganda, or even self-display, but equal communication and friendly interaction based on sympathized understanding that really counts most. Thirdly, we should be endowed with free spirits and calm attitudes. All those remarkable and distinguished literature works and cultural ideas could be created and produced in a comfortable and delighted atmosphere. Last, every successful cultural communication is firmly built on the solid foundation of cross-cultural thinking and practice.

\section{To Choose, but Not to Instill in the Process of Cultural Interaction and Integration}

The sympathetic response is very important when one culture has the influence on another culture; both cultures have the rights to make choices. Voltaire, a French enlightenment thinker and philosopher, once said that China was a good example for France to follow, and China was indeed an ideal country, no matter from the perspective of politics, law, the attitude towards religion, or morality, and way of dealing with people. He even said that the happiest and most respectable era in history was when we followed the law proposed by Confucius, and China was a good example for him to criticize his own culture. In the mega trend of globalization, what we are facing is a great civilization's rejuvenation with a long-standing history of five thousand years whose depth, breadth and intensity in cultural development is unprecedented in human history. We are fully confident in making our original contributions to the world civilization, being capable of learning virtues of other civilizations without losing our own, neither showing off, nor instilling our culture into other cultures.

It's a noble mission for the modern people, especially the people along the Silk Road countries, to maintain and develop the Silk Road cultures. We should, first of all, pay attention to the academic research in the Silk Road cultures to preserve and spread the huge amount of cultural legacy and master works worthy of elaborate collection and sorting. Secondly, it's of great importance to create particular brands of Silk Road cultures to increase their creativity in order to strengthen the appealing power of the Silk Road products. Finally, it's high time that we establish personnel exchange and training unions to promote academic cooperation among the famous universities and research institutions, sharing the Silk Road cultural recourses and striving for common educational and cultural development of all the Silk Road countries.

\section{CONCLUSIONS}

The world has transformed into a new age advocating mutual dependence, multilateral cooperation and common development without competing values, antagonism and conflicts. China, as a responsible great nation, puts forward the Belt and Road Initiative in due time with great foresight and high practicability. According to the comprehensive framework and delicate details of this historic initiative, we should not only fulfill the fundamental mission of economic cooperation and development to realize common welfare, but also strengthen people-to-people bonds through intercultural exchange and appreciation. Culture is the root of an ethnic group and the source of the vitality of a nation, so the top priority of establishing friendly relationship with a foreign country is to approach and understand its abundant cultural meaning as a brilliant mixture of different civilization achievements, diverse life styles and traditional values. Only with culture-equality awareness and culture-appreciation grace can we open the door to carry out cultural exchange and interaction. The ancient Silk Road not only achieved commercial legends among China and other Silk Road countries, but also witnessed brilliant cultural movements among a great number of ethnicities and nations. Today, the economic energy and cultural vitality of this ancient road is revived under the framework of the Belt and Road Initiative and our great mission today is to establish and enhance mutual trust in culture, to make great contributions to the common development and prosperity in and beyond cultures and to ultimately attain the goal of building a community of shared future for all humankind.

\section{ACKNOWLEDGEMENTS}

The research is financed by the Social Science Association Project of Dalian City No.2017dlskyb145: A Study on Cultural Construction and Development Strategies of Dalian Sea Silk Road City Based on One Belt One Road Initiative. 


\section{REFERENCES}

[1] Baidu Wenku. Silk Road and Cultural Exchange. [EB/OL] From http://blog.sina.com.cn/s/blog_8dfa9ca20101ouw0.html, (2017-02-19).

[2] D. G. Bates \& F. Plog. (1990). Cultural Anthropology, 3d ed. New York: McGraw-Hill, 28.

[3] Hu Wenzhong. (1999). Introduction to Intercultural Communication. Beijing: Foreign Language Teaching and Research: 1-2.

[4] L. A. Samovar, R.E. Porter, L. A. Stefani. (2000). Creation Communication between Cultures. Beijing: Foreign Language Teaching and Research: 48.

[5] L. S. Harms. (1973). Intercultural Communication. New York: Harper \& Row, 8.

[6] News Agency. Looking back at three years' achievements of One Belt One Road. [EB/OL] From http://www.scio.gov.cn/ztk/wh/slxy/31200/Document/1493006/1493006.html, (2016-10-08)

[7] Richard Brislin, Kenneth Cushner, Craig Cherrie and Mahealani Yong. (1986). Intercultural Interactions: A Practical Guide. Sage Publications: 73-74, 99-100.

[8] Robert Hanvey. (1979). Cross-Cultural Awareness. In Elise Smith \& Louise Luce, Toward Internationalism: Readings in Cross-Cultural Communication. New York: Newbury Publisher, 53-54.

[9] Shi Yan. (2016). Probe on Resources of Li Zehou's Ideological Core of Sentiment. Manager Journal: (34) 218-220.

[10] WEI Li. (2017). Construction of Humanistic Silk Road with Sharing Cultures and Intercommunicating Souls based on Chinese Civilization Wisdom. IOSR-JRME: (1)1-5.

[11] Zhao Guangcheng. (2017). To Probe the Chinese Soft Power under the Background of Belt and Road Initiative. [EB/OL] http://www. OBOR100. com (accessed 01/06/2017).

[12] Zhao Tingyang. (2011). Tianxia System. Beijng: Renmin University of China Press: 10-30.

Chengcheng Liu is currently studying in the School of Liberal Arts, Renmin University of China. His English academic papers include An Optimized Study on Chinese and American Flipped Classroom Mode: from the Cultural Perspective published by IOSR Journal of Research \& Method in Education in 2016, A Creative Design and Implementation of Student-led Flipped Classroom Model in English Learning published by English Journal of TPLS in 2016, A Case Study on the Construction on Ubiquitous Personalized English Learning Resources for High School Students by International Journal on Studies in English Language and Literature in June 2016, A Study on Maker Education and Its Integration into College English Teaching by IOSR Journal of Research \& Method in Education in Sep. 2017. 